\title{
Use of Drills and Secondary School Students' Achievement in the English Language Spelling
}

\author{
Dr. Chinyere Henrietta Maduabuchi \\ Dept. of Arts and Social Science Education, Faculty of Education \\ Ebonyi State University, Abakaliki, Ebonyi State,Nigeria \\ ettachimlo@yahoo.com \\ Iheanacho, Kindness Amara \\ Department of General Studies \\ Federal College of Agriculture, Ishiagu, Ebonyi State \\ kindforall@yahoo.com
}

\begin{abstract}
The discrepancies in the spelling pattern and oral articulation of words in the English language reveal the reasons why English is often regarded as a difficult subject to a second language learner. This could be exemplified in the six different pronunciations of 'ough' articulated thus in the following words: bough, cough, thorough, thought, through, and rough. This subtle, but obvious challenge of mastery could be attributed to pedagogical issues. The repeated abysmal failures in English language in West African Examination Councils and National Examinations' Council (NECO) SSCE examination and the consequent lamentation of the WAEC Chief examiners' report necessitated this research. This study adopted a pretest post test quasi experimental research design with four intact classes of SSII students, who were subjected to treatment and control. Two research questions and two hypotheses guided the study and a sample of 264 students (comprising 107 males and 157 females) were used. The validation and test of reliability were accurately done. The instrument for data collection was the English Language Achievement Test (ELAT) which was developed by the researcher. Data collected were analyzed using the inferential statistics of mean and standard deviation for the research questions and Analysis of Covariance (ANCOVA) for the hypotheses at 0.05 level of significance. The results of study revealed amongst others that there was a significant difference in the scores of students taught English language spelling with drills and those taught with the conventional method; while the second hypothesis was accepted, which shows that there is no significant difference in the performance of male and female students taught spellings with drills. Based on these results, recommendations were made on the need for teachers to adopt drill method in teaching spelling to SSII students because of its dynamic traits.
\end{abstract}

Keywords: Drills, Spelling, English Language, Achievement, Secondary School.

\section{INTRODUCTION}

English Language is the primary language of the majority of people in the United Kingdom, the United States, Canada, Australia, New Zealand, other former colonies of Britain, and territories of the United States. It is also an official or semi-official language of many countries with a colonial past, such as India, Nigeria, Pakistan, and South Africa. Even in countries where English is not a primary or official language, it is taught as a foreign language and used as the language of technology and diplomacy. English language is spoken in more parts of the world and by more people than any other language, except Chinese (Ker, 2002).

In Nigeria for instance, English language was introduced when the Great Britain colonized territories in Africa. Being a multi-lingual country, Nigeria has since adopted the English language as her Lingua Franca. As a matter of fact, of the entire heritages that were left behind by her colonial masters, probably none is more important than the English language. It has now become the language of government, business, commerce, education, the mass media, literature and much internal as well as international communication.

Apart from speech, which is informal, reading and writing are very important communication skills for everyone, especially for students in a formal set-up. To write well, one has to spell well. However, Bell (2004) observed that many students find spelling very difficult because they equate spoken words 


\section{Dr. Chinyere Henrietta Maduabuchi \& Iheanacho, Kindness Amara}

to the written form. They reason that if a writing system closely mirrors the spoken word, then differences in written forms will indicate differences in pronunciation and language usage. Nonetheless, those familiar with English orthography (spelling) know that this is not always the case.

Both speakers of English as their native language, and those who speak it as a second language, regard the spelling of English as one of its most difficult characteristics. The English spelling system is not based on a phonetic correspondence between sounds and letters, as is the spelling in Spanish and certain other languages. Instead, English spelling reflects the historical development of the language. The same combination of letters can produce different pronunciations (Okoli, 2000). Similarly, different combinations of letters can produce the same pronunciation. The six different pronunciations of 'ough' provide an apt example of the discrepancy between spelling and pronunciation, as in bough, cough, thorough, thought, through, and rough. Although -ough is spelt the same in each of these words, it is pronounced in six different ways. Again, the letter ' $\mathrm{i}$ ' is pronounced ' $/ \mathrm{i} /$ ' in the word 'fish'. The same letter is pronounced '/ $\alpha \mathrm{i} /$ ' in 'find'. Furthermore, the ' $a$ ' in 'cap' is pronounced /æ/, while the same letter is pronounced / $\alpha: /$ in 'class' and /a/ in 'above'. These differences in pronunciation make up one reason why English is considered a difficult language for non-native speakers to learn (McAthur \& McAthur, 2001).

This problem might well explain the poor performance of students in WAEC-organized examinations in Nigeria, especially in the English language. In fact, Fatuase (2010) analyzed the results of the West African Senior School Certificate Examinations of candidates who obtained credit passes in at least five subjects, including the English language and mathematics and concluded that it was worrisome. For the year 2005, it was $27.53 \%$ of the total population of candidates. In 2006, it was $15.56 \%$, $25.54 \%$ in $2007,13.76 \%$ in 2008 and $25.99 \%$ in 2009.

In summary, he complains that:

It is disheartening to note that some candidates are unmindful of their handwritings. Some of them cannot write some of the letters and numbers properly and this makes scoring of their responses not only difficult but also inaccurate. No matter how brilliant a student is, his intelligence will come to naught if he cannot manifest it by way of accurate response to questions before him in an examination (p. 46).

From the report above, a number of very relevant variables can be isolated. For instance, students' interest and attitude to sharpening their skills in handwriting and spelling is generally poor and the will to correct the anomaly is either low or non-existent. Teachers on their part display low commitment to this cause when they do not complete their respective syllabuses. Sometimes too, the methods employed, and the nonchalant attitude exhibited by the teachers, are most inappropriate in relation to the target population. This further clogs the stream of content assimilation and retention on the part of the students.

Earlier in an address by the head of Nigeria national office of the West African Examinations Councils at a press briefing held to announce the release of results of the November/ December 2008 WASSCE at the council's office in Yaba, Lagos, on Friday, February 20, 2009, it was revealed that of the total number of candidates that sat for the examination, 127,200 candidates, representing $34.1 \%$, obtained credits and above in at least five (5) subjects, including the English language or mathematics. Among them are 66,353 (17.8\%) male candidates, and 60,847 (16.3\%) female candidates. Similarly, 176,783 candidates representing $47.5 \%$ obtained credits and above in four (4) subjects, while 221,851 candidates representing 59.5\% obtained credits and above in three (3) subjects. A total number of 266,505 candidates, or $71.5 \%$ obtained credits and above in two (2) subjects. Among the candidates that obtained credits and above in five (5) subjects, including the English Language and Mathematics, the results show that 29,268 candidates, $7.9 \%$ are science oriented; 7,552 candidates, $2.0 \%$ are social science biased, while 29,527 candidates, 7.9\% are Arts oriented.

Recently, in the Vanguard of Thursday, April 24, 2014, a communique issued at the end of the 57th meeting of the Nigeria Examination Committee of the West Africa Examination Council (WAEC) noted that there was a decline in the performance of candidates in English Language. Reasons tendered for this trend include:

inadequate preparation and rote memorization, illegible handwriting... misinterpretation of the demands of the questions and difficulty in framing their responses due to poor command of the English Language... inability to marshal their points and answers to questions that required detailed explanations, inability to spell technical words correctly (pp. 25-6). 
In the light of these challenges, the Nigeria-WAEC committee provided some solutions and called on stakeholders, especially students, to "make effort to improve upon their understanding of the English Language in order to appreciate the requirements of the questions and make their responses appropriate and coherent" (p. 26).

Much of the English written by most people in Nigeria seems to be sub-standard, characterized by poor spelling. In fact, to a large extent, the print and electronic media are recognized, or acknowledged, as potent forces or channels for disseminating spoken and written words. Most times though, these media authorities disregard the $100 \%$ performance mentality, and thus violate most known rules of the English language. It is believed that while good spelling cannot make an essay, bad spelling can spoil it. Spelling errors erode the content quality of write-ups.

Furthermore, the ugly trend in students' performance in English language and spelling has been attributed to the traditional approach used in the teaching of the subject in secondary schools. Aliyu (2002) observed that the success or failure of any educational endeavour or the effectiveness of any learning experience depends ultimately on the method adopted by the teacher. It has been established that conventional methods of teaching the English language and spelling are inadequate and even problematic (Johnson and Johnson, 2003; Routman, 2006). It is noteworthy that drills are seldom used to teach spelling in our secondary schools. The closest method to drill one sees is dictation, which is grossly inadequate for the intended objective.

Additionally, there is the speculation that science courses are for male students while females are better in literary arts and Home Economics (Ezeh, 2007). Contrary to these opinions, Okoye (2007) opines that neither boys nor girls are superior in intelligence. Okoye's stand indicates that gender has no influence on students' achievement in any subject. This shows that there exists controversy on the effect of gender on students' performances in different subjects or fields. This research work throws more light on the controversies highlighted.

Generally, the purpose of this research is to determine the use of drills and students' collective achievement in the spelling of the English Language words in secondary schools in Afikpo Education Zone. It will also determine if there is a gender-induced variation in students' achievement in the spelling of the English language words when drills are used to teach them. These give rise to the following research questions:

1. What is the effect of the use of drills on the mean achievement scores of students in the spelling of the English language words?

2. What is the effect of the use of drills on the mean achievement scores of male and female students in the spelling of the English language words?

\section{REVIEW OF RELATED LITERATURE}

Related literature on the nature of spelling in the English language, functions of the letters, spelling irregularities, spelling patterns, concept of drills, gender and academic achievement were reviewed and the theories of behviourism, cognitivism and constructivism informed the work. These theories focus on learning as observable aspects of learning in which the learner actively constructs or builds new ideas or concepts.

\section{Nature Of Spelling in the English LANGUAGE}

The essential and distinguishing attributes of spelling in the English Language are quite interesting. The English language has relatively complex spelling rules when compared to other languages with alphabetic orthographies (the alphabetic spelling system used by a given language) (Ker, 2002). Because of the complex history of the English language, nearly every sound can be legitimately spelt in more than one way. This is because sounds do not perfectly mirror the words they represent. The examples below illustrate this: the sound / $z$ / can be spelt 'ss' as in 'possess', ' $z$ ' as in 'zoo' and 's' as in 'nose'; the sound /f/ can be spelt 'ph' as in 'phonology', 'gh' as in 'laugh' and 'f' as in 'roof'; the sound / $/$ / can be spelt 'ss' as in 'passion', 't' as in 'lotion', 'c' as in 'ocean', 'ch' as in 'chef', 'sh' as in 'parish' and 'shoe', and so on. In like manner, many words can be legitimately pronounced in more than one way. Some words are spelt the same way but pronounced differently. This is called homograph. For example, the word 'wind' can be pronounced /w Ind/ as in 'air that moves quickly as a result of natural forces' as well as /waInd/ as in 'to wrap or twist something around itself or something else, or to turn a handle several times'. 


\section{FUNCTIONS OF THE LETTERS}

Most spellings have to do with phonemic representations. Like most alphabetic systems, letters in English orthography may represent a particular sound. For example, the word 'yam' (pronounced $/ \mathrm{jæm} /$ ) consists of three letters ' $y$ ', ' $a$ ', and ' $m$ ', in which 〈y〉 represents the sound $/ \mathrm{j} /$, ' $a$ ' the sound $/ \mathfrak{l} /$, and $\langle\mathrm{m}\rangle$ the sound $/ \mathrm{m} /$. Single letters or multiple sequences of letters may provide this function. Thus, the single letter ' $y$ ' in the word 'yam' represents the single sound $/ \mathrm{j} /$. In the word ship (pronounced $/ \int_{\mathrm{I}} \mathrm{p} /$ ), the digraph 'sh' (two letters) represents the sound $/ \mathrm{J} /$. In the word ditch, the three letters 'tch' represent the sound $/ \mathrm{t} / \mathrm{f}$. Less commonly, a single letter can represent multiple sounds voiced in succession. The most common example is the letter ' $x$ ' which normally represents the consonant cluster/ks/. For example, the word 'ex-wife' is pronounced /eks'wa Iff/ (Okoli, 2000).

The same letter (or sequence of letters) may indicate different sounds when it occurs in different positions within a word. For instance, the digraph 'gh' represents the sound /f/ at the end of some words, such as 'rough' $/ \mathrm{r} \Lambda \mathrm{f} /$. At the beginning of syllables (i.e. the syllable onset), the digraph «gh〉 represents the sound /g/, such as in the word 'ghost' (pronounced/goust/). Another type of spelling characteristic has to do with the origin of words. For example, when representing a vowel, the letter 〈y〉 in non-word-final positions, represents the sound /I/ in some words borrowed from Greek, whereas the letter usually representing this sound in non-Greek words is the letter ' $i$ '. Thus, the word 'myth', pronounced $/ \mathrm{mI}_{\mathrm{I}} \theta /$, is of Greek origin, while 'pith', pronounced $/ \mathrm{p}_{\mathrm{I}} \theta /$, is a Germanic word (Bell, 2009).

Some researchers such as Brengelman (2001), have suggested that, in addition to this marking of word origin, these spellings indicate a more formal level of style or register in a given text, although Rollins (2004) finds this point to be exaggerated as there would be many exceptions where a word with one of these spellings, such as 'ph' for /f/ (like telephone), could occur in an informal text. Generally, few spellings can be got through orthography, but many through sounds. This is because English, like many other languages, has many homophones (words that have the same sounds, that is, pronounced the same way but may differ in meaning or spelling, or in both). For example, 'bare' and 'bear', 'eye' and 'I', 'some' and 'sum', 'sun' and 'son', etc.

Spelling may also be used to distinguish between homophones. For example, the words 'hour' and 'our' are pronounced identically in some dialects (as /av(e)r/). However, they are distinguished from each other orthographically by the addition of the letter ' $h$ '. Another example is the pair of homophones 'plain' and 'plane', where both are pronounced /'ple In/ but are marked with two different orthographic representations of the vowel sound /e I/ (Araromi, 2002). In some cases however, some homophones have no distinguishing factor in their sound production. Below are some examples:

- Be and bee, been and bean, heal and heel, meat and meet, peace and piece, scene and seen, steal and steel, week and weak;

- Board and bored, coarse and course, morning and mourning, warn and worn;

- Blew and blue, flew and flu, through and through, two and too, root and route;

- Berth and birth, curb and kerb, fir and fur, heard and herd;

- Berry and bury, bread and bred, lead and led, weather and whether;

- Brake and break, stake and steak, male and mail, sale and sail, tail and tale, rain and reign, wait and weight, way and weigh;

- I'll and isle, buy and by, hi and high, hire and higher, write and right;

- Allowed and aloud, foul and fowl;

- Know and no, loan and lone, pole and poll, road and rode, roll and role, sew and so;

- Air and heir, bare and bear, fair and fare, pair and pear, stair and stare, wear and ware;

- Knew and new, knight and night, knot and not;

- Ascent and assent, base and bass, cell and sell, scent and sent, cereal and serial; 
- Guessed and guest, leased and least, passed and past, etc.

In written language, this may help to resolve potential ambiguities that may arise (e.g. 'He will write it' versus 'He will right it'). The particular edge or advantage written language has over the spoken language in this regard is that the reader often has no recourse to ask for clarification.

On the other hand, homographs make spelling a lot easier than homophones, since one will not have a hard time trying to decipher which meaning of a set of homographs he is to spell. For example, the word 'bay' has at least five fundamentally different meanings. The table below illustrates this assertion:

Table1. Applications of the Homograph 'Bay'

\begin{tabular}{|l|l|}
\hline Word & Meaning \\
\hline Bay & $\begin{array}{l}\text { 1. curved inlet of sea: an area of sea enclosed by a wide inward-curving stretch of coastline } \\
\text { 2. land with curving hills around: a lowland area with curving hills partly surrounding it }\end{array}$ \\
\hline $\begin{array}{l}\text { Bay } \\
\text { (2) }\end{array}$ & $\begin{array}{l}\text { 1. special area or compartment: an area that is divided off and used for a particular purpose, e.g. } \\
\text { 2. space between two pillars: a section of a wall or building between two vertical structures such as } \\
\text { pillars or buttresses } \\
\text { 3. recess: a recess or alcove in a wall }\end{array}$ \\
\hline $\begin{array}{l}\text { Bay } \\
\text { (3) }\end{array}$ & $\begin{array}{l}\text { 1. reddish brown colored animal: an animal with a reddish brown coat, especially a horse } \\
\text { 2. reddish brown: a reddish brown color }\end{array}$ \\
\hline (4) & $\begin{array}{l}\text { 1. tree with aromatic leaves: a small evergreen tree of the laurel family with stiff dark green } \\
\text { aromatic leaves. Use: flavoring in cooking. Native to: Mediterranean. Latin name: Laurus nobilis }\end{array}$ \\
\hline $\begin{array}{l}\text { 1. } \text { intransitive verb) howl: to make the howling sound of a hunting dog on the trail of an animal } \\
\text { 2. (intransitive verb) make loud outcry for something: to call noisily and aggressively for } \\
\text { something bad to happen to somebody (e.g., an outraged public baying for blood) } \\
\text { 3. (transitive verb) corner hunted animal: to corner or exhaust a hunted animal so that it must turn } \\
\text { and face its hunters (e.g., hounds baying a fox) } \\
\text { 4. (noun) position of no escape: the position in which a hunted animal or a person being pursued } \\
\text { has to face the hunters or pursuers } \\
\text { 5. keep somebody or something at bay: to keep somebody or something unpleasant at a distance } \\
\text { to avoid difficulty or harm }\end{array}$ \\
\hline
\end{tabular}

Source: Microsoft Encarta, 2009.

\section{SPELling IRREgULARITIES}

Attempts to regularize or reform the language, including spelling reform, have usually met with failure. The only significant exceptions were the reforms of Noah Webster which resulted in many of the differences between British and American spelling, such as center/centre, dialog/dialogue, honor/honour, grammar/grammer, program/programme, etc. Other differences, such as -ize/-ise in realize/realise etc, came about separately (Bell, 2004).

Apart from the twists the English spelling system has inherited from its past, there are other idiosyncrasies in spelling that make it tricky to learn. English contains 25 separate consonant phonemes and 20 vowel sounds. However, there are only 26 letters in the modern English alphabet, so there cannot be a one-to-one correspondence between letters and sounds. Many sounds are spelt using different letters or multiple letters, and for those words whose pronunciation is predictable from the spelling, the sounds denoted by the letters depend on the surrounding letters. For example, the digraph ' $t h$ ' represents two different sounds (the voiced dental fricative and the voiceless dental fricative). The voiceless alveolar fricative /s//z/ can be represented by the letters ' $s$ ', ' $c$ ' and ' $z$ ' (Okoli, 2000).

Bell (2009) however noted that it is not the shortage of letters that makes English spelling irregular. Its irregularities are caused by the use of many different graphemes for some of its sounds, such as the long sounds which are: /i:/, /a:/, / :/, /u:/, /3:/ (as exemplified in the words meat, bee, people; class, farm, yard, fall, cord, floor; do, school, shoe, blue; birth, bird, Thursday), and the use of identical graphemes for spelling different sounds (over, oven, move, ever, never).

Furthermore, English makes no attempt to spell most recent loanwords in the English way, but preserves the foreign spellings, even when they employ exotic conventions like the Polish 'cz' in Czech or the old Norse 'fj' in fjord (although New Zealand English exclusively spells it fiord). In fact, 
instead re-spelling loan words to conform to English spelling standards, the pronunciation changes in response to pressures associated with the spelling. One example of this is the word 'ski', which was adopted from Norwegian in the mid-18th century. It used to be pronounced 'shee', which is similar to the Norwegian pronunciation, but the increasing popularity of the sport after the middle of the 20th century helped the ' $s k$ ' pronunciation replace it (Bell, 2004).

Moreover, other causes of spelling irregularities still exist. For instance, at a time, the English language noticed an alteration in the spelling of some words. This was a misguided attempt to conform to 'etymology' (which is perceived to be the origin of the words). For example, the letter ' $b$ ' was added to debt (originally dette) in an attempt to link it to the Latin 'debitum', and the letter ' $s$ ' in island is a misplaced attempt to link it to Latin insula instead of the Norse word 'igland', which is the true origin of the English word. The letter ' $p$ ' in 'ptarmigan' has no etymological justification whatsoever. Some are just randomly changed: for example, 'score' used to be spelled 'skor' (Emerson, 1997).

The spelling of English continues to evolve. Many loanwords come from languages where the pronunciation of vowels corresponds to the way they were pronounced in Old English, which is similar to the Italian or Spanish pronunciation of the vowels, and is the value the vowel symbols [a], [e], [i], [o], and [u] have in the International Phonetic Alphabet. As a result, there is a somewhat regular system of pronouncing "foreign" words in English (Carney, 2004), and some borrowed words have had their spelling changed to conform to this system. For example, 'Hindu' used to be spelt 'Hindoo', and the name 'Maria' used to be pronounced like the name 'Mariah', but was changed to conform to this system. It has been argued that this influence probably started with the introduction of many Italian words into English during the Renaissance, in fields like music, from which come the words andante, viola, forte, etc (Venezky, 2006).

Another major influence that has had a profound effect on the spelling of the English language words is the contribution of commercial advertisers. In an attempt to differentiate their products from others and make their unique, they introduce new or simplified spellings like 'lite' instead of 'light', 'thru' instead of 'through', 'smokey' instead of 'smoky' and 'rucsac' instead of 'rucksack'. The spellings of personal names have also been a source of spelling innovations. Affectionate versions of women's names that sound the same as men's names have been spelt differently. For example: 'Nikki' and 'Nicky', 'Toni' and 'Tony', 'Jo' and 'Joe'.

As examples of the distinctive nature of English spelling, the combination ' $o u$ ' can be pronounced in at least six different ways: /a/ in famous, /3:/ in journey, /av/ in loud, /\%/ in should, /u:/ in you,/vo/ in tour; and the long vowel sound /i:/ has about nineteen (19) realizations and can be spelt in those different ways. Some examples include: paediatric, me, seat, seem, ceiling, people, chimney, machine, siege, phoenix. The palato-alveolar fricative $/ \int /$, for instance, has up to twelve (12) spelling patterns and the diphthong /a I/ has twenty-six (26) realizations. So spelling these sounds with the appropriate letters pose a lot of problems and thus contribute to spelling irregularities.

The average English-speaking child takes nearly three times longer to learn the basics of reading and writing than users of other alphabetic writing systems (Seymour, Aro \& Erskine, 2003). Numerous surveys in Anglophone countries during the past five decades have established that nearly half of all English speakers have severe difficulties with writing. One in five cannot even read properly, as was confirmed in 2005 by the UK's House of Commons Select Committee for Education.

The English writing system is uniquely difficult because it has spelling and reading problems. Other difficult alphabetic systems have only spelling problems. To become even just moderately competent spellers of English, learners have to memorize at least 3700 words with some unpredictable spellings. No other European language has more than 1000 unpredictable spellings (Bell, 2004).

\section{Spelling Patterns}

In a generative approach to English spelling, Rollins (2004) identifies twenty main orthographic vowels of stressed syllables that are grouped into four main categories: "Lax", "Tense", "Heavy", "Tense-R". (As this classification is based on orthography, not all orthographic "lax" vowels are necessarily phonologically lax.) 
Table2. Orthographic Vowels of Stressed Syllables

\begin{tabular}{|c|c|c|c|c|c|c|c|c|c|}
\hline \multicolumn{5}{|c|}{ General Pronunciation (American) } & \multicolumn{5}{|c|}{ Received Pronunciation (American) } \\
\hline Letter & Lax & Tense & Heavy & Tense-R & Letter & Lax & Tense & Heavy & Tense-R \\
\hline $\mathbf{a}$ & $\frac{\operatorname{m} /}{m a n}$ & $\frac{\text { le } \mathrm{I} /}{\text { mane }}$ & $\begin{array}{l}\text { lad } \\
\text { mar } \\
\end{array}$ & $\frac{\mid \varepsilon /}{\text { mare }}$ & a & $\frac{\mid æ /}{m a n}$ & $\frac{\text { le } \mathrm{I} /}{\text { mane }}$ & $\frac{\text { la:/ }}{m a r}$ & $\frac{/ \varepsilon \partial /}{\text { mare }}$ \\
\hline $\mathbf{e}$ & $\frac{\mid \varepsilon /}{m e t}$ & $\frac{\text { li/ }}{\text { mete }}$ & $\begin{array}{l}\text { l3/ } \\
\text { her }\end{array}$ & $\frac{\text { /I } /}{\text { here }}$ & $\mathbf{e}$ & $\frac{\mid \varepsilon /}{m e t}$ & $\frac{\text { li:/ }}{\text { mete }}$ & $\begin{array}{l}\text { lz:- } \\
\text { her }\end{array}$ & $\frac{\text { / I } \mathrm{al}}{\text { here }}$ \\
\hline i & $\frac{/ \mathrm{I} /}{\operatorname{win}}$ & $\frac{\text { /a I / }}{\text { wine }}$ & $\begin{array}{l}\text { I3/ } \\
\text { fir }\end{array}$ & $\frac{\text { lail }}{\text { fire }}$ & $\mathbf{i}$ & $\frac{/ \mathrm{I} /}{\operatorname{win}}$ & $\frac{\text { /a I / }}{\text { wine }}$ & $\begin{array}{l}\text { I3:I } \\
\text { fir }\end{array}$ & $\frac{\text { la ial }}{\text { fire }}$ \\
\hline $\mathbf{0}$ & \begin{tabular}{|l|} 
lal \\
mop \\
\end{tabular} & $\frac{\text { lov/ }}{\text { mope }}$ & $\begin{array}{l}\text { lol } \\
\text { for, fore }\end{array}$ & & & $\mathbf{o}$ & $\frac{/ \mathrm{p} /}{m o p}$ & $\frac{\text { /оU/ }}{\text { mope }}$ & $\frac{\text { lo:/ }}{\text { for, fore }}$ \\
\hline $\mathbf{u}$ & $\frac{\mid \Lambda /}{h u g}$ & $\begin{array}{l}\text { /ju/ } \\
\text { huge }\end{array}$ & $\begin{array}{l}\text { I3/ } \\
\text { cur }\end{array}$ & $\frac{\text { ljol }}{\text { cure }}$ & $\mathbf{u}$ & $\frac{/ \Lambda /}{h u g}$ & $\frac{\text { /ju:/ }}{\text { huge }}$ & $\begin{array}{l}\text { /3:/ } \\
\text { cur }\end{array}$ & $\frac{\text { /juə/ }}{\text { cure }}$ \\
\hline $\mathbf{u}$ & $\frac{1 \mathrm{Jl}}{p u s h}$ & $\begin{array}{l}\mathrm{u} / \\
\text { rude }\end{array}$ & - & $\frac{1 \mathrm{~J} /}{\text { sure }}$ & $\mathbf{u}$ & $\frac{l v l}{p u s h}$ & $\frac{\mathrm{lu}: /}{\text { rude }}$ & - & $\frac{\text { lool }}{\text { sure }}$ \\
\hline
\end{tabular}

Source: Rollins, 2004

The above shows that the pronunciation of a word can pose a little problem to its spelling. For instance, the letter ' $a$ ' can represent the lax vowel /æ/, tense /e I/, heavy /a:/, or tense-r $/ \varepsilon(ə) /$. Heavy and tense ' $r$ ' vowels are the respective lax and tense counterparts followed by the letter ' $r$ '. Further, when the word 'sure' is pronounced the American way, it might be difficult for a second language learner to associate its spelling with 'sure' pronounced the British way.

Tense vowels are distinguished from lax vowels with a "silent" ' $e$ ' letter that is added at the end of words. Thus, the letter ' $a$ ' in hat is lax /æ/, but when the letter ' $e$ ' is added in the word ' $h a t e$ ' the letter ' $a$ ' is tense /e I/. Similarly, heavy and tense ' $r$ ' vowels pattern together: the letters ' $a r$ ' in 'car' are heavy /ar/, the letters ' $a r$ ' followed by silent ' $e$ ' in the word 'care' are / $\varepsilon ə r /$. The letter ' $u$ ' represents two different vowel patterns, one being /j/, the other / $\mathrm{u} / /$. There is no distinction between heavy and tense ' $r$ ' vowels with the letter ' $o$ ', and the letter ' $u$ ' in the $/ v-u$ :- $\mho /$ pattern does not have a heavy vowel member (Rollins, 2004).

Besides silent $e$, another strategy for indicating tense and tense-r vowels, is the addition of another orthographic vowel forming a digraph. In this case, the first vowel is usually the main vowel while the second vowel is the "marking" vowel. For example, the word man has a lax $a$ pronounced /æ/, but with the addition of $i$ (as the digraph ai) in the word 'main' the ' $a$ ' is marked as tense and pronounced /e I/. These two strategies produce words that are spelt differently but pronounced identically, as in mane (silent $e$ strategy), main (digraph strategy) and Maine (both strategies). The use of two different strategies relates to the function of distinguishing between words that would otherwise be homonyms (which means words that have the same spelling and pronunciation patterns; or homographs and homophones put together).

Besides the 20 basic vowel spellings, Rollins (2004) has a reduced vowel category (representing the sounds $/ \mathrm{\partial}, \mathrm{I} /$ ) and a miscellaneous category (representing the sounds $/ \mathrm{\rho}$, av, a I, av/ and $/ \mathrm{j} /+\mathrm{V}, / \mathrm{w} /+\mathrm{V}$, $\mathrm{V}+\mathrm{V})$.

\section{CONCEPT OF DRILLS}

Drill, as an academic concept, is a relatively novel phenomenon. But for the purpose of context, we would understand drill as a disciplined, repetitious exercise employed as a means of teaching and perfecting a skill or procedure. In other words, it is a sequence of tasks, exercises, or words repeated over and over until they can be performed faultlessly, as used in teaching military skills, languages, or basic arithmetic (Microsoft, 2009). Spelling drill therefore means to name or write in correct order the constituent letters of a word, part of a word, or group of words.

Drill and practice systems are intended to supplement the instruction which occurs in the classroom. They are designed to improve - through practice - the skills and concepts that are introduced by the classroom teacher. They also encourage teachers to think about ways to make drilling more meaningful. Mumford (2002) proffered remarkable suggestions on effective strategies for teaching and learning the spelling of the English language words using drills. These suggestions cover when drilling on intonation, when drilling on different ways of saying words, when drilling on spelling, when drilling on vocabulary, when drilling on polite requests, and when drilling about grammar. 


\section{GENDER AND ACADEMIC ACHIEVEMENT}

Gender is a concept that is now being widely used in the field of education (Ogba and Ndaba, 2006). Gender refers to all the characteristics and the expected roles of men and women that a particular society has determined and assigned each sex (Emetarom, 2000). Oakely (1996) and Okeke (2000) define gender as socially constructed roles and learned behaviors as well as expectations associated with males and females. These definitions present gender as a social creation derived from certain assumptions about the nature and character of biological differences between males and females. On the other hand, Abubakar and Uboh (2010) define gender as those properties that distinguish organisms on the basis of their reproductive roles as females or males. This definition however presents gender as a natural phenomenon.

Deliberations and debates on the effect gender has on cognitive abilities have, for a long time, been polarized between biological factors and social factors. The biological factors school of thought trivializes the contributions of social factors and argues that brain structure, for instance, is a powerful determinant in the level of performance or achievement between males and females. On several occasions from several studies carried out, Lynn (1998a, 1998b, 1999; Allik, Must and Lynn, 1999; Colom and Lynn, 2004) strongly holds that 'males have larger average brain sizes than females and therefore, would be expected to have higher IQs' (Dayı_lu and Türüt-A_1k, 2004). Intelligence Quotient or General intelligence is here defined as the sum of verbal comprehension, reasoning and spatial (three or four-dimensional) abilities.

On the other side of the divide, a major proponent of the social factors school of thought, Mackintosh (1998) argues that gender difference does not determine general intelligence. He further postulated that general intelligence should be defined in terms of reasoning ability, with Progressive Matrices as the most appropriate way or formula to measure it. The Standard Progressive Matrices was constructed in the late 1930s as a test of non-verbal or abstract reasoning ability and the Advanced Progressive Matrices was constructed in 1947 as a more difficult version of the test suitable for those in the higher ability range (Lynn and Tse-Chan, 2003).

Nwafor (2008) observes that during the colonial era in Nigeria, most schools had predominantly male students. The schools basically aimed at producing literate men that would serve the white man. Ezeliora (2002), notes that in early times, the education of women and girls was seen as a wasted investment. This was because their duty in the society did not require such education. When girls were allowed access to formal education, domestic science was about the only course of study open to them (Allele-Williams, 1988). This stance is corroborated by Lassa (1995) who reveals that girls were made to do art subjects like needlework, nutrition, home management, music and the like. This observation is supported by (Ezeliora (2002) who states that "from earlier times, boys received more encouragement and support to study science while girls were not made to be in touch with the real science subjects". In most parts of the world, women are channeled to Liberal Arts and social science subjects, while men are encouraged to take up the hard core sciences.

According to Nnachi (2002), for years now, expectations for boys differ from expectations for girls in certain courses or subjects, thus enhancing gender stereotyping in academic activities. Witting and Williams (1984), state that teachers treat boys differently from girls, and tend to associate reading skills with girls and mathematical skills with boys. There seem to be speculations that boys perform better than girls in science subjects and that girls perform better than boys in art subjects. Omojuwa and Uguma (2003) are of the view that girls perform in verbal tests and tests involving memory than boys. They also agree that boys perform better in tests requiring inductive reasoning and arithmetic ability. In line with this opinion, Bottomley and Sampson (1987) are of the view that boys generally perform better academically than girls. However, some authors disagree with this notion and are of the view that there is no difference in intelligence between males and females that can be traced to gender. For instance, Okoye (2007) argues that the fact that men are regarded as a dominant and even superior sex does not mean that they are intellectually better than women. Agreeing with Okoye, Denga (1986) states that there is no evidence to show that there is a difference between males and females in academic achievement that is traceable to gender. Denga, however is of the opinion that girls tend to do better than boys in arts and languages, while boys tend to perform better than girls in mathematics and sciences. 
There seems, therefore, to be a general perception that art subjects are designed for girls while science subjects are for boys. Agheyisi (1999) relates that formal education was for ages regarded as the exclusive preserve of males, and it now seems that modern technological scientific studies remain, in most cases, the privilege of men. Traditional gender symmetry has over the years continued to limit women's capabilities and constrain their chances to participate in all spheres of human endeavor (Ngonebu, 2002).

\section{Method OF RESEARCH}

The study adopted a quasi-experimental design using the pre-test post-test non-equivalent control groups. Intact classes were used so as to eliminate the randomization of subjects into control and experimental groups. The areas of study were Ivo and Ohaozara Local Government Areas in Afikpo Education Zone of Ebonyi State. The population of the study comprised 4,854 SS II students in the 80 public secondary schools in Afikpo Education Zone. The sample size for this study was 264 students (comprising 107 males and 157 females) drawn from four (4) intact classes of SS II students. These intact classes were selected through a simple random sampling technique from four (4) secondary schools from two local government areas, that is, Ivo and Ohaozara Local Government Areas in Afikpo Education Zone. Two schools were drawn from each local government area.

The instrument for data collection was the English Language Achievement Test (ELAT) which was developed by the researcher. The instrument comprised two sections: A and B. Section A contained information on the personal data of the testees while section B contained the 40 test items of ELAT. Items in Section A sought the personal data of the respondents, while items in Section B were grouped under the following aspects: parts of speech, oral English, determiners, subjective cases of nouns, objective cases of nouns, idioms and adjunct. The instrument was a multiple-choice test with four options each: A, B, C, D. There was only one correct answer among the options. A student was expected to tick the correct answer from among the options. The instrument was used for both the pretest and post-test. However, the items in the pre-test were reshuffled before administering them as post-test. The research questions were analyzed using mean and standard deviation while the hypotheses were tested using the Analysis of Co-variance (ANCOVA) at 0.05 level of significance.

\section{RESULTS AND DisCUSSIONS}

\subsection{Research Question 1}

What is the effect of the use of drills on the mean achievement scores of students in the spelling of the English language words?

Table3. Mean and Standard Deviation Results of Achievement based on Teaching Methods

\begin{tabular}{|l|l|l|l|}
\hline Teaching Methods & N & Mean & Std Dev \\
\hline Use of Drill & 131 & 25.75 & 7.90 \\
\hline Use of conventional teaching method & 133 & 23.38 & 7.30 \\
\hline
\end{tabular}

From Table 3, the students that were taught spelling of the English language words with the use of drills had an adjusted mean score of 25.75 and a standard deviation of 7.90 while those taught the same lessons with the use of conventional teaching methods had an adjusted mean of 23.38 and a standard deviation of 7.30. This means that an application of drills as a teaching method in the English language spelling lessons has a positive effect on the achievement of students when tests are administered in that subject area. Their mean test scores increased, showing that the treatment made them perform better in their assessments.

\subsection{Research Question 2}

What is the effect of the use of drills on the mean achievement scores of male and female students in the spelling of the English language words?

Table4. Mean and Standard Deviation of Achievement based on Gender

\begin{tabular}{|l|l|l|l|l|l|l|}
\hline \multicolumn{2}{|l|}{ Males } & \multicolumn{2}{l|}{ Females } \\
\hline Teaching Methods & N & Mean & Std Dev & N & Mean & Std Dev \\
\hline Use of Drills & 59 & 26.32 & 7.16 & 72 & 25.27 & 8.48 \\
\hline Conventional Teaching Method & 48 & 22.39 & 7.90 & 85 & 23.51 & 6.94 \\
\hline & & & & & & \\
\hline
\end{tabular}




\section{Dr. Chinyere Henrietta Maduabuchi \& Iheanacho, Kindness Amara}

From Table 4, male students had an adjusted mean of 26.32 and a standard deviation of 7.16 when taught spelling of the English language words using drills as a teaching method, while their female counterparts had an adjusted mean of 25.27 and a standard deviation of 8.48. On the other hand, male students had an adjusted mean of 22.39 and a standard deviation of 7.90 when taught spelling of the English language words using conventional method, while their female counterparts had an adjusted mean of 23.51 and a standard deviation of 6.94 .

This result is quite interesting. When male and female students are taught the English language spelling together using drills as the preferred teaching method, the males perform better than females in achievement tests. However, when a conventional method is used to teach the same topic, females perform better in achievement tests. On the other hand, when the students are separated along gender lines and taught spelling of the English language words in isolation, both sexes perform better in achievement tests when drill is used as the teaching method rather than the conventional teaching method.

\subsection{Hypothesis 1}

There is no significant difference in the mean achievement score of students when taught spelling in the English language with drills and when taught with conventional teaching methods.

Table5. ANCOVA Results of Achievement based on Methods of Teaching

\begin{tabular}{|l|l|l|l|l|l|l|}
\hline Source of Variation & Sum of Squares & df & Mean Square & F-cal & Sig of F & F-crit \\
\hline Covariates & 52.244 & 1 & 52.244 & .900 & .344 & \\
\hline Pretest & 52.244 & 1 & 52.244 & .900 & .344 & \\
\hline Main Effects & 409.059 & 1 & 409.059 & 7.049 & .008 & \\
\hline Methods & 409.059 & 1 & 409.059 & 7.049 & .008 & 3.84 \\
\hline Explained & 461.303 & 2 & 230.651 & 3.974 & .020 & \\
\hline Residual & 15147.027 & 261 & 58.035 & & & \\
\hline Total & 15608.330 & 263 & 59.347 & & & \\
\hline
\end{tabular}

* Significant at $P<0.05$

Table 5 shows the result of an ANCOVA analysis of the data collected with pretest value as covariates. Since the calculated value of $F$ is greater than its critical value, the null hypothesis was rejected and this signifies that there was a significant difference in the mean achievement score of students when taught spelling in the English language with drills and when taught with conventional teaching methods.

Since this result rejected the null hypothesis, there arises a need to carry out a Multiple Classification Analysis (MCA) in order to determine the degree of contribution of each treatment. Table 6 shows the results of the MCA analysis.

Table6. Multiple Classification Analysis based on Methods of Teaching

Grand Mean $=24.42$

\begin{tabular}{|l|l|l|l|l|l|}
\hline Variable + Category & $\mathbf{N}$ & $\begin{array}{l}\text { Unadjusted } \\
\text { Deviation }\end{array}$ & Eta & $\begin{array}{l}\text { Adjusted for Independents + } \\
\text { Covariates Deviation }\end{array}$ & Beta \\
\hline Use of Drill & 131 & 1.33 & & 1.30 & \\
\hline Conventional Method & 133 & -1.31 & .17 & -1.28 & .17 \\
\hline Multiple R squared & & & & & .030 \\
\hline Multiple R & & & & & .172 \\
\hline
\end{tabular}

From table 6 above, the multiple classification analysis result shows a grand mean of 24.42. It follows that the adjusted grand mean for students taught spelling of the English language words using drills becomes $24.42+1.30=25.72$. On the other hand, the adjusted mean for students taught using conventional method becomes $24.42+(-1.28)=23.14$. The glaring difference between the mean scores is significant.

\subsection{Hypothesis 2}

There is no significant difference in the mean achievement score of male and female students when taught spelling in the English language with drills and when taught with conventional teaching methods. 
Use of Drills and Secondary School Students' Achievement in the English Language Spelling

Table7. ANCOVA Results of Achievement based on Gender

\begin{tabular}{|l|l|l|l|l|l|l|}
\hline Source of Variation & Sum of Squares & df & Mean Square & F-cal & Sig of F & F-crit \\
\hline Covariates & 52.244 & 1 & 52.244 & .877 & .350 & \\
\hline Pretest & 52.244 & 1 & 52.244 & .877 & .350 & \\
\hline Main Effects & 3.399 & 1 & 3.399 & .057 & .811 & \\
\hline Gender & 37399 & 1 & 3.399 & .057 & .811 & 3.84 \\
\hline Explained & 55.644 & 2 & 27.822 & .467 & .627 & \\
\hline Residual & 15552.686 & 261 & 59.589 & & & \\
\hline Total & 15608.330 & 263 & 59.347 & & & \\
\hline
\end{tabular}

* Not significant at $P<0.05$

Table 7 shows the result of an ANCOVA analysis of the data collected with pretest value as covariates. The results showed an F-cal value of 0.057 and an F-crit value of 3.84. Since the calculated value of $\mathrm{F}$ is less than its critical value, the null hypothesis was accepted. This means that there was no significant difference in the mean achievement score of male and female students when taught spelling in the English language with drills and when taught with conventional teaching methods. Since this result accepted the null hypothesis, there was no need to carry out a Multiple Classification Analysis (MCA).

\section{SUMMARY OF FindingS}

From the mean and standard deviation results, this study has revealed that the use of drills as a teaching method in the English language spelling lessons has a positive effect on the achievement of students when tests are administered in that subject area. This stance was corroborated by the test result of the first hypothesis. It held that the difference between the achievements of students in the spelling of the English language words when taught such using drill as a teaching method is quite significant when compared to that of students taught using conventional teaching methods.

The mean and standard deviation figures of the test result further showed that when male and female students were brought together and taught spelling of the English language words using drill as the teaching method of choice, the males performed better than the females when achievement tests are administered. On the other hand, when the same group was taught the same topic using conventional teaching method, females performed better than the males in achievement tests. This disparity though was not captured by the test result of the second hypothesis. It saw no significant difference in the mean achievement score of male and female students when taught spelling in the English language with drills and when taught with conventional teaching methods. However, when taught spelling of the English language words in isolation, both sexes perform better in achievement tests when drill is used as the teaching method rather than the conventional teaching method.

This suggests that males generally need more practice to get a piece or stream of knowledge stuck in their memory. Therefore, if a class is made up of only male students or consists of mixed sexes, use of drills should be applied in the teaching of the spelling of the English language words. If the class is made up of only female students though, it does not matter which teaching method is adopted.

\section{Conclusion}

The study has shown that the use of drills in the teaching of the spelling of the English language words had significant effect on the students' cognitive achievement in the English language assessment tests. The use of drills thus appears to be a more effective teaching method than the conventional one as far as spelling of the English language words is concerned. It is hoped that when this formula is expanded to incorporate other classes in schools and extended to cover other schools, the results will be as encouraging as presupposed by this investigation.

\section{RECOMMENDATIONS}

- Since it has been discovered that the use of drills as a method in teaching the spelling of the English language words generally makes students perform better, it is highly recommended. Teachers of the English language should without fear avail themselves to the application of this teaching method during their classes.

- Principals and internal supervisors in the schools should ensure that teachers of the English language employ drills when teaching the spelling of the English language words. 
- Students should be encouraged to have drill practice sessions at home and in their leisure times. This can be done by giving them take-home assignments.

- Parents and guardians should assist their children and wards to sharpen their spelling skills by overseeing the execution of such take-home assignments.

- Government should organize in-service trainings and workshops for teachers on how to improve their resourcefulness in teaching, especially as it relates to languages.

- Qualified teachers, with requisite training in education and the English language, should be recruited to teach the English language in schools.

- Curriculum planners should also spot and capture these areas of need in subsequent updates to versions of the English language curriculum.

- Authors in this field of the English language should be guided by the results of this research work as they churn out relevant academic materials.

\section{REFERENCES}

Abubakar, R. B., \& Uboh, V. (2010). Breaking the gender barrier in enrolment and academic achievement of science and mathematics students. Akoka Journal of Pure and Applied Science Education, 10, 203-213.

Abubakar, R. B., \& Oguguo, O. D. (2011). Age and gender as predictors of academic achievement of college mathematics and science students. Journal of Educational and Social Research, 1, 192197.

Abonyi, O. S., \& Eze A. O. (2006). Effects of geo-board on junior secondary school student's achievement in geometry. Ebonyi State University Journal of Education, 4, 243-250.

Agheyisi, R. U. (1999). The labor market: Implications of the access of women to higher education in Nigeria. Women in Nigeria Today. London: Zeb Books.

Allele-Williams, G. (1988). Science, technology and mathematics education for all including women and girls in Africa. A Keynote Address at the Commonwealth of Africa Regional Workshop, Accra, Ghana.

Aliyu, J. S. (2002). Enhancing the teaching of English language in Nigerian secondary schools. Perspectives on Applied Linguistics in Language and Literature. Ibadan: Stirling-Horden Publishers (Nig) Ltd.

Allik, J., Must, O., \& Lynn, R. (1999). Sex differences in general intelligence among high school graduates: Some results from Estonia. Personality and Individual Differences, 26, 1137-1141.

Araromi, M. (2002). Issues in planning reading improvement in secondary schools. Perspectives on applied linguistics in language and literature. Ibadan: Stirling-Horden Publishers (Nig) Ltd.

Bell, M. (2004). Understanding English spelling. Cambridge: Pegasus.

Bell, M. (2009). Rules and exceptions of English spelling. Cambridge: Pegasus.

Bottomley, M., \& Sampson, B. (1987). The case of the female principal: Sex role attitudes and perception of sex differences in ability. Australian and New Zealand Journal of Sociology, 13, $137-140$.

Brengelman, F. H. (2001). Generative phonology and the teaching of spelling. English Journal, 59, 1113-1118.

Cameson, M. B., \& Wilson, B. J. (2011). Effect of chronological age, gender and delay of entry on academic achievement and retention: Implications for academic redshirting. Psychology in the Schools, 27, 260-263.

Carney, E. (2004). A survey of English spelling. London: Routledge.

Colom, R., \& Lynn, R. (2004). Testing the developmental theory of sex differences in intelligence on 12-18 year olds. Personality and Individual Differences, 36, 75-82.

Day1o_lu, M., \& Türüt-A_1k, S. (2004). Gender differences in academic performance in a large public university in Turkey. ERC Working Papers in Economics, 4, 17.

Denga, D. I. (1986). Educational measurement, continuous assessment and psychological testing. Calabar: Rapid Educational Publishers. 
Emetarom, U. G. (2000). Analysis of gender access and inequality in school enrolment: Implication for UBE program in Nigeria. The Nigeria Academy of Education. Benin City: Ambik Press Ltd.

Emerson, R. (1997). English spelling and its relation to sound. American Speech, 72, 260-288.

Eniayeju, A. A. (2010). Effects of cooperative learning strategy on the achievement of primary six boys and girls in mathematics. ABACUS: The Journal of Mathematical Association of Nigeria, $35,1-9$.

Eze, P. I. (2002). Effects of picture on the performance of secondary school students in christian religious knowledge from Bible texts. International Journal of Arts and Technology Education, 2, 153-158.

Ezeh, S. O. (2007). Gender inequality in Nigerian society: Causes and suggestions for developing gender-fair society. Journal of Education for Professional Growth, 3, 168-173.

Ezeliora, B. (2002). Interaction effects of learning material types and gender on students' achievement, retention and interest in chemistry. Ebonyi State University Journal of Education, $1,75-84$.

Fatuase, T. (2010, January 7). WAEC: Same old reasons for failure. The Nation, p. 43.

Igbeyi, A. (2002). Effects of communicative language teaching methods on the achievement of students in English reading comprehension Doctoral Thesis from University of Nigeria, Nsukka, Nigeria.

Johnson, D., \& Johnson, R. (2003). Impact of cooperation and individualistic learning on high ability students' achievement, self-esteem and social acceptance. Journal of Social Psychology, 13, 835839.

Ker, D. I. (2002). The choice of English as a national language for Nigeria: A revaluation. perspectives on applied linguistics in language and literature, 89-97. Ibadan: Stirling-Horden Publishers (Nig) Ltd.

Lassa, P. N. (1995). Entrepreneurship education or socio-economic and industrial development in Nigeria. A Keynote Address Presented during the National Conference on Entrepreneurship Education at Federal College of Education (Technical), Umunze, Nigeria.

Lynn, R. (1998a) Sex differences in intelligence: A rejoinder to Mackintosh. Journal of Biosocial Sciences, 30, 529-532.

Lynn, R. (1998b) Sex differences in intelligence: Some comments on Mackintosh and Flynn. Journal of Biosocial Sciences, 30, 555-559.

Lynn, R. (1999) Sex differences in intelligence and brain size: A developmental theory. Intelligence, 27, 1-12.

Lynn, R., \& Tse-Chan, P. W. (2003). Sex differences on the progressive matrices: Some data from Hong Kong. Journal of Biosocial Sciences, 35, 145-150.

Mackintosh, N. J. (1998) Reply to Lynn. Journal of Biosocial Sciences, 30, 533-539.

Maduabuchi, C. H. (2006). Effects of literature circles and collaborative learning strategies on students' comprehension of poetry. Ebonyi State University Journal of Education, 4 ,184-194

McArthur T., \& McArthur, F. (2001). The Oxford companion to the English language. London: Oxford University Press.

Microsoft. (2009). Encarta. Microsoft corporation® 1993-2008.

Mumford, S. (2002). Drilling can be fun. The Internet TESL Journal, 8.

Ngonebu, C. L. (2002). Gender discrimination and communicative competence in science and technology. International Journal of Arts and Technology Education, 2, 27-44.

Nnachi, R. O. (2002). Relationship between gender and science self-concept among senior secondary school students of some south eastern states of Nigeria. Journal of Education, 1, 85-89.

Nwafor, C. E. (2008). Effect of jurisprudential model of instruction on the achievement of junior secondary school students in integrated science A Doctoral Thesis of Ebonyi State University, Abakaliki, Nigeria.

Nworgu, B. G. (1995). Evaluating the effects of resource material types relative to students' cognitive achievement, retention and interest in integrated science. A Dissertation, University of Nigeria, Nsukka, Nigeria). 
Oakely, A. (1996). Sex, gender and society. England: Gower Publishing Company Ltd.

Ogah, M. E. U. (2006). Effects of communicative language teaching methods on junior secondary school students' achievement and interest in the French language A Dissertation, Ebonyi State University, Abakaliki, Nigeria.

Ogba, F. N., \& Ndaba, M. O. (2006). Gender imbalance in education: Strategies for equal educational opportunities. Ebonyi State University Journal of Education, 4, 234-242.

Okeke, E. A. C. (2000). Gender equity/equality in education. A Lead Paper Presented at the $3^{\text {rd }}$ Annual Conference of the World Council for Curriculum and Instruction (WCCI), Nigeria, Abuja.

Okoli, L. A. (2000). The tongue of English. Enugu: Hugotez Publications.

Okoye, N. N. (2007). Learner characteristics and human learning. Onitsha: Leading Books.

Olayemi, O. O. (2009). Students' correlates and achievement as predictors of performance in physical chemistry. ABACUS: The Journal of Mathematical Association of Nigeria, 34, 99-105.

Omojuwa, J. O., \& Uguma, V. C. (2003). Gender and environmental differences in the achievement of senior secondary school students in reading comprehension in English language in Cross River state, Nigeria. Journal of Faculty of Education, University of Calabar, 3, 63-75.

Owolabi, J., \& Etuk-Irien, O. A. (2009). Gender, course of study and continuous assessment as determinants of students' performance in Pre-NCE mathematics. ABACUS: The Journal of Mathematical Association of Nigeria, 34, 106-111

Rollings, A. G. (2004). The spelling patterns of English. Lincom Studies in English Linguistics, 4.

Routman, R. (2006). Literacy at the crossroads. USA: Heinemann.

Seymour, P. H. K., Aro, M., \& Erskine, J. M. (2003). Foundation literacy acquisition in European orthographies. British Journal of Psychology, 94, 143-174.

Shupe, M. J., \& Yager, G. (2011). Self-concept, social isolation, and academic achievement in college students with and without learning disabilities. Retrieved from http//:wwwshsu.edu/ piic/ fall2005/shupe.html

Teo, B. G., \& Teh, G. P. L. (1987). The effectiveness of using instructional objectives with less able secondary school pupils. Australian Journal of Educational Technology, 3, 135-144.

Udegbe, G. I. (2009). Students' interest as an important factor in improving the teaching and learning of mathematics. Proceedings of September 2009 Annual Conference of Mathematical Association of Nigeria (MAN.), 77-83.

Venezky, R. L. (2006). Notes on the history of English spelling. Visible Language, 30, 351-365.

Witting, A. F., \& Williams, G. (1984). Psychology: An introduction. New York: McGraw Hill Inc. 